\title{
PENGARUH PEMBELAJARAN KELOMPOK DALAM UPAYA MENINGKATKAN KEMAMPUAN PEMAHAMAN KONSEP MATEMATIKA BERBASIS MASALAH
}

\author{
Puji Astuti $^{1}$, Anggi Saputra ${ }^{2}$ \\ 1.2Program Studi Pendidikan Matematika, STKIP Insan Madani Airmolek \\ Pujiastuti2695@gmail.com ${ }^{1}$
}

\begin{abstract}
Abstrak
Penelitian ini merupakan penelitian kualitatif dengan tujuan untuk mengetahui kendalakendala yang dihadapi oleh siswa baik itu ketika mengerjakan soal sendiri, maupun dikerjakan secara berkelompok. Teknik pengumpulan data yang digunakan dalam penelitian ini adalah teknik komunikasi langsung, dimana peneliti melakukan kontak langsung dengan responden melalui tatap muka. Instrumen yang digunakan dalam penelitian ini adalah tes dan wawancara. Siswa diberikan tes terkait dengan materi sistem persamaan linear dua variabel. Tes ini dimaksud untuk mengetahui kemampuan siswa dalam memahami konsep matematika dan wawancara dilakukan untuk mengetahui kesulitan yang dihadapi oleh siswa. Setelah data diperoleh kemudian dianalisis menggunakan triangulasi data. Dari hasil penelitian ini diperoleh bahwa siswa yang berada pada kelompok dapat saling bertukar pikiran dalam memahami konsep matematika materi sistem persamaan linier dua variabel daripada siswa yang mengerjakan soal secara mandiri. Dapat disimpulkan pembelajaran kelompok mempermudah siswa dalam memahami konsep karena adanya proses pertukaran pikiran saat memahami konsep dari suatu masalah.
\end{abstract}

Kata Kunci: Konsep, Kelompok, Masalah

\begin{abstract}
This research is a qualitative research with the aim of knowing the obstacles faced by students both when working on their own questions or in groups. The data collection technique used in this research is direct communication, where the researcher makes direct contact with the respondent face to face. The instruments used in this study were tests and interviews. Students are given tests related to the system of two-variable linear equations. This test is intended to determine the ability of students in understanding mathematical concepts and interviews are conducted to determine the difficulties faced by students. After the data was obtained, it was analyzed using data triangulation. From the results of this study, it was found that students who were in the group could exchange ideas in understanding the mathematical concepts of the two-variable linear equation system material rather than students who worked on the problems independently. It can be concluded that group learning makes it easier for students to understand the concept because of the process of exchanging thoughts when understanding the concept of a problem.
\end{abstract}

Keywords: Concepts, Groups, Problem

\section{PENDAHULUAN}

Perkembangan sains dan teknologi sangatlah pesat dalam berbagai ilmu pengetahuan, termasuk matematika. Perkembangan ini haruslah dijaga dan ditingkatkan, terutama pada proses pembelajaran. Proses pembelajaran yang akan mendorong siswa dan guru untuk meningkatkan kemampuan pemahaman konsep matematika. Untuk meningkatkan proses pembelajaran, dibutuhkan metode pembelajaran yang baik. Metode pembelajaran yangdipraktikkan oleh saat ini masih bersifat masih bersifat konvensional yang mana pembelajaran berasal dari guru. Sehingga siswa hanya sekedar menerima informasi yang berasal dari guru hal ini menyebabkan siswa bosan 
dan sulit untuk memahami materi pembelajaran. Untuk itu guru perlu mempersiapkan metode dan strategi untuk mempermudah proses pembelajaran.

Sudjana (2005) menyatakan bahwa metode pembelajaran adalah cara yang dipergunakan guru dalam mengadakan hubungan dengan siswa pada saat berlangsungnya pengajaran. Sejalan dengan itu Sutikno (2009) menyatakan bahwa metode pembelajaran merupakan cara-cara menyajikan materi pelajaran yang dilakukan oleh pendidik agar terjadi proses pembelajaran pada diri siswa dalam upaya mencapai tujuan. Menurut Salamun (2009) metode pembelajaran merupakan sebuah cara-cara yang berbeda untuk mencapai hasil pembelajaran yang berbeda di bawah kondisi yang berbeda. Sehingga dapat disimpulkan bahwa motode pembelajaran merupakan cara yang dipakai atau digunakan oleh guru sebagai pendidik dalam mengelola pembelajaran agar tercapai tujuan pembelajaran yang telah ditetapkan.

Selain memilih metode yang tepat selama pembelajaran, seorang guru juga harus memiliki pengetahuan yang luas dalam mengembangkan konteks materi pelajaran.Jennifer, M.George., and Jones Gareth. R. (2012) menyatakan bahwa seorang guru harus memiliki pengetahuan yang luas untuk mengembangkan konten matematika dan juga seorang guru harus terampil untuk memperluas pemikiran siswa. Menurut Setiani dan Donni (2015) guru yang paripurna adalah guru yang menguasai keterampilan dasar mengajar secara baik. Keterampilan dasar mengajar wajib dikuasai guru sebelum memulai pembelajaran. Guru harus menguasai keterampilan dasar mengajar dalam proses pembelajaran. Hal ini dipertegas oleh Mukminan, dkk (2013) keterampilan dasar mengajar adalah kecakapan atau kemampuan pengajar dalam menjelaskan konsep terkait dengan materi pembelajaran. Jadi, seorang pendidik harus mempunyai persiapan mengajar. Persiapan tersebut diantaranya harus menguasai bahan pembelajaran, mampu memilih strategi, metode dan media, penguasaan kelas yang baik, serta menentukan sistem penilaian yang tepat.

Suryono dan Hariyanto (2011) bahwa keterampilan dasar yang harus dimiliki seorang pendidik pada hakikatnya terkait dengan tafsiran sejauh mana kemampuan para guru mampu di dalam menerapkan berbagai variasi metode mengajar. Dari pendapat ahli di atas menjelaskan bahwa seorang guru memerlukan pemahaman tentang latar belakang pengetahuan peserta didik, lingkungan belajaranya, dan tujuan pembelajaran untuk menentukan metode yang digunakan ketika mengajar. Selanjutnya menurut Djamarah (2005) keterampilan dasar mengajar adalah keterampilan yang mutlak harus guru miliki dalam mengoptimalkan perannya dikelas. Metode pembelajaran dapat mempengaruhi kemampuan pemahaman konsepsiswa.

Pemahaman konsep merupakan salah satu aspek yang sangat penting dalam pembelajaran, karena dengan memahami suatu konsep materi siswa dapat mengembangkan kemampuannya dalam materi pelajaran tersebut. Pemahaman konsep sendiri terdiri dari dua kata yaitu pemahaman dan konsep. Menurut Depdiknas (2006) pemahaman dapat didefinisikan sebagai suatu proses memahami arti atau makna tertentu dan kemampuan menggunakannya pada situasi lainnya. Murizal (2002) mengemukakan bahwa pemahaman merupakan tingkat kemampuan yang mengharapkan siswa mampu memahami arti atau makna konsep, situasi, atau fakta yang diketahuinya. Senada dengan hal ini, senada dengan hal ini, Arikunto, S (2008) mengungkapkan pemahaman adalah bagaimana seseorang membedakan, menduga, memperluas, menyimpukan, memberikan contoh, menuliskan kembali dan memperkirakan. Konsep adalah ide yang digunakan atau memungkinkan seseorang untuk mengelompokkan/menggolongkan suatu objek (Wardhani, 2008). Senada dengan hal itu, Dimyati (2002) mengatakan bahwa konsep merupakan ide abstrak yang digunakan untuk menggolongkan sekumpulan objek. 
Konsep adalah segala sesuatu yang berwujud pengertian-pengertian, ciri khusus, hakikat danisi dari materi matematika (Gusniwati, M 2015). Sejalan dengan itu Rahmawati (2015)menyatakan bahwa konsep dapat diartikan sebagai suatu sistem satuan arti yang mewakili sejumlah objek yang mempunyai ciri-ciri yang sama. Dari definisi konsep menurut para ahli dapat disimpulkan bahwa konsep merupakan segala sesuatu yang dapat digolongkan menjadi sekumpulan objek.

Pemahaman konsep adalah suatu kemampuan menentukan ide abstrak dalam matematika untuk mengklasifikasikan objek-objek yang biasanya dinyatakan dalam suatu istilah kemudian dituangkan kedalam contoh atau bukan contoh, sehingga seseorang dapat memahami suatu konsep dengan jelas (Gusniwati, 2015). Senada dengan ituYunuka (2016) mengatakan bahwa pemahaman konsep adalah kemampuan bersikap, berpikir dan bertindak yang ditunjukkan oleh siswa dalam memahami definisi, pengertian ciri khusus, hakikat dan inti atau isi dari matematika dan kemampuan dalam memilih prosedur tepat dalam menyelesaikan masalah.

Berdasarkan pendapat di atas maka dapat disimpulkan bahwa pemahaman konsep adalah suatu kemampuan menemukan ide abstrak dalam matematika untuk mengklasifisikan objek-objek yang biasanya dinyatakan dalam suatu istilah kemudian dituangkan kedalam contoh dan bukan contoh, sehingga seseorang dapat memahami suatu konsep dengan jelas.

Salah satu kecakapan dalam matematika yang penting dimiliki oleh siswa adalah pemahaman konsep. Untuk mengukur kemampuan pemahaman konsep diperlukan alat ukur (indikator), hal tersebut sangat penting dan dapat dijadikan pedoman pengukuran yang tepat.

Kemampuan pemahaman konsep matematika seorang guru dapat ditingkatkan dengan cara mengambil sebuah atau lebih suatu metode pembelajaran. Metode pembelajaran yang diambil dapat berupa metode pembelajaran kelompok. Johan, B. $\mathrm{N}$ (2008) mengemukakan suatu pembelajaran kelompok terdiri dari siswa yang saling bekerja sama untuk mencapai tujuan pembelajaran dan menyelesaikan masalah secara bersama. Penggunaan metode kelompok dapat membuka jendelapemikiran siswa dalam memahami konsep pembelajaran matematika materi SPLDV. Siswa yang saling bertukar fikiran dalam menyelesaikan konsep sistem persamaan linear dua variabel yang ditimbulkan dari suatu masalah yang diberikan. Maka dari itu diperlukan pemahaman konsep secara bersama-sama dari suatu masalah yang muncul. Sehingga perlulah diadakan upaya pembelajaran kelompok dalam upaya peningkatan kemampuan pemahaman konsep berbasis masalah pada materi SPLDV. Karna menurut Jhonson and Rising (2006) mengatakan bahwa matematika adalah pola fikir, pola mengorganisasikan secara logis. Untuk itulah dibutuhkan pemahaman konsep siswa terhadap materi yang dipelajari.

Kemampuan pemahaman konsep tidak hanya berkaitan pada satu kemampuan/keahlian yang dimiliki oleh siswa saja. Dalam pemahaman konsep diperlukan kemampuan-kemampuan lainnya. Robert Kreitner (2005) menyatakan bahwa yang dimaksud kemampuan merupakan karakteristik stabil yang berkaitan dengan kemampuan maksimum fisik mental seseorang. Sedangkan menurut Mc Shere\&Glinow (2007) kemampuan adalah kecerdasan alami dan kapabilitas dipelajari yang diperlukan untuk menyelesaikan tugas. Dapat disimpulkan bahwa kemampuan merupakan kecerdasan dan kecakapan yang dimiliki oleh seseorang dalam menyelesaikan suatu permasalahan.

Kemampuan seorang siswa dalam menyelesaikan masalah matematika sejalan dengan pemahamannya. Bruno (2010)berpendapat bahwa pemahaman adalah sebuah proses persepsi yang secara tiba-tiba muncul dengan adanya ketertarikan yang terjadi dalam keseluruhan. Maka dari itu seseorang akan memahami sesuatu secara tiba-tiba seiring dengan berjalannya waktu. 
Sejalan dengan itu Devis, Keith and Newstrom (2001) mengemukakan terdapat empat kriteria seseorang dikatakan memahami konsep: (a) Dapat menyatakan atributnya; (b) Dapat memberikan contoh konsep; (c) Dapat memberikan contoh non konsep; (d) Dapat memberi nama dan mendefinisikannya.Jaffey Liker (2005)menyatakan bahwa masalah adalah sebuah peluang untuk menuju kehidupan yang lebih baik.

Dalam pembelajaran matematika materi Sistem Persamaan Linear Dua Variabel (SPLDV) materi yang menuntut siswa untik paham dengan konsep matematika. Karena pada materi ini siswa mempelajari dua buah persamaan linier atau lebih yang menggunakan dua buah variabel dan mempunyai satu jawaban yang sama.

Pengamatan yang dilakukan oleh peneliti dengan melakukan pemberian soal materi SPLDV yang dikerjakan sendiri yang hasilnya itu tidak memuaskan, masih dengan subjek yang sama peneliti melakukan pembentukkan kelompok untuk mengerjakan soal yang sama, dan hasilnya peneliti dapati bahwa hasil pembelajaran sangat memuaskan. Dimana subjek tersebut melakukan diskusi dan saling bertukar fikiran.

Materi Sistem Persamaan Linear Dua Variabel (SPLDV) merupakan salah satu pokok pembahasan mata pelajaran matematika di kelas VIII SMP/MTS semester ganjil yang membahas tentang hubungan variabel satu dengan variabel yang lain. Dalam kehidupan sehari-hari, banyak masalah perhitungan dapat diselesaikan dengan menerapkan SPLDV, diantaranya masalah keuangan, bisnis, umur dan sebagainya. Untuk dapat menyelesaikan permasalahan di atas, siswa diharapkan mampu memahami konsep SPLDV dan terampil dalam memecahkan masalah dalam kehidupan sehari-hari. Dalam kegiatanpembelajaran matematika pada materi SPLDV, kesulitan yang umumnya dirasakan oleh siswa adalah sulit menemukan konsep berhitung dari SPLDV sehingga apabila bentuk soal diubah siswa tidak mampu menyelesaikan soal yang diberikan sehingga hasil belajar yang diperoleh siswa menurun. Hal tersebut terjadi karena dalam proses pembelajaran matematika kebanyakan cara penyampaian materi pembelajaran masih secara konvensional dimana pembelajaran masih berpusat pada apa yang diajarkan oleh guru, sehingga siswa masih menjadi objek belajar yang hanya mengikuti instruksi guru untuk mendengar, mencatatmateri pelajaran, dan menghafal sederatan rumus. Suatu alternatif yang dapat membuat pembelajaran matematika lebih menarik dan siswa dapat berperan aktif untuk menciptakan suatu suasana yang menarik dalam pembelajaran. Maka dari itu, peneliti menarik kesimpulan untuk mengambil judul "Pengaruh Pembelajaran Kelompok dalam Upaya Meningkatkan Kemampuan Pemahaman Konsep Matematika Berbasis Masalah pada Materi Sistem Persamaan Linier Dua Variabel."

\section{METODE}

Penelitian ini menggunakan metode penelitian kualitatif. Metode penelitian kualitatif adalah penelitian yang digunakan untuk meneliti pada kondisi objek alamiah, dimana peneliti merupakan instrumen kunci (Sugiyono, 2005). Dalam penelitian ini peneliti mengamati gerak-gerik yang ditimbulkan oleh siswa saat sedang menyelesaikan masalah baik itu didalam kelompok maupun individu.

Instrumen yang digunakan dalam penelitian ini adalah tesdan wawancara. Instrumen tes berupa soal Sistem Persamaan Linier Dua Variabel (SPLDV). Sampel dalam penelitian ini adalah siswa kelas VIII. Tujuan dalam penelitian ini adalah untuk mengetahui kendala-kendala yang dihadapi oleh siswa baik itu ketika mengerjakan soal sendirian, maupun dikerjakan secara kelompok. Dalam pengambilan sampel peneliti menggunakan teknik purposive sampling. Sampel yang diambil adalah siswa Sekolah Menengah Pertama (SMP) yang memiliki daya pikir dan kemampuan pemahaman konsep matematika yang bervariasi. Dimana siswa dapat melakukan penyelesaian masalah sesuai dengan apa yang mereka ketahui. 
Teknik pengumpulan data yang digunakan dalam penelitian ini adalah teknik komunikasi langsung yang merupakan mekanisme pengumpulan data yang dilakukan melalui kontak atauhubungan pribadi dalam bentuk tatap muka diantara pengumpul data dan responden (Nawawi, H \& Hadari, M.M, 1992). Setelah data dikumpulkan kemudian dianalisis dengan menggunakan Triangulasi data. Analisa dituangkan dalam bentuk tulisan atau wawancara yang didapat saat penelitian berlangsung. Pada analisis data difokuskan terhadap suatu yang diteliti, telah dikaji melalui berbagai teori yang dikemukakan.

Tes tertulis dilakukan dengan menyuguhkan lima butir soal Sistem Persamaan Linear Dua Variabel (SPLDV) yang dikerjakan secara individu dan kelompok. Tes ini bertujuan untuk mengetahui penguasaaan siswa terhadap materi Sistem Persamaan Linier Dua Variabel (SPLDV) yang menjadi materi pokok penelitian ini. Pada tes ini diketahui bahwa siswa hanya memahami sedikit konsep dari materi Sistem Persamaan Linier Dua Variabel (SPLDV).

Menurut Nawawi (2005) wawancara adalah usaha mengumpulkan data atau informasi dengan mengajukan pertanyaan secara lisan, untuk menjawab secara lisan pula. Jadi disimpulkan bahwa wawancara merupakan teknik pengumpulan data yang dilakukan secara langsung dengan mengajukan berbagai pertanyaan secara lisan.

Pada kegiatan wawancara diketahui letak-letak kesulitan siswa pada saat menyelesaikan soal yang diberikan secara individu. Komunikasi yang mereka lakukan saat diskusi kelompok membuat upaya penyelesaian soal menjadi lebih mudah. Mereka saling berkomunikasi untuk menyelesaikan soal dan menghasilkan pertukaran pikiran sehingga soal lebih mudah diselesaikan melalui diskusi yang mana mereka melakukan pertukaran informasi yang mereka ketahui tentang konsep Sistem Persamaan Linier Dua Variabel (SPLDV).

\section{HASIL PENELITIAN DANPEMBAHASAN}

Berdasarkan penelitian yang telah dilakukandapat dikemukakan bahwa dalam mengerjakan soal terdapat kendala-kendala yang ditemui baik pada saat mengerjakan soal secara mandiri maupun berkelompok.Siswa melakukan penyelesaian masalah sesuai dengan masalah yang diberikan. Dari masalah yang diberikan terlihat bagaimana pemahaman siswa terhadap pemahaman konsep yang terdapat pada masalah. Pada tahap pertama penelitian dilakukan dengan memberikan masalah yang diselesaikan secara mandiri atau sendiri. Berikut masalah yang dikemukakan.

individu.

Dalam sebuah tempat parkir terdapat 90 kendaraan yang rerdiri atas mobil beroda 4 dan sepeda motor beroda 2. Jika dihitung roda keseluruhan ada 248 buah. Biaya parkir sebuah mobil Rp. 5.000, sedangkan untuk sebuah sepeda motor Rp. 2.000. Berapa pendapatan uang parkir dari kendaraan yang ada tersebut?

Berikut merupakan jawaban subjek A yang mengerjakan soal secara individu

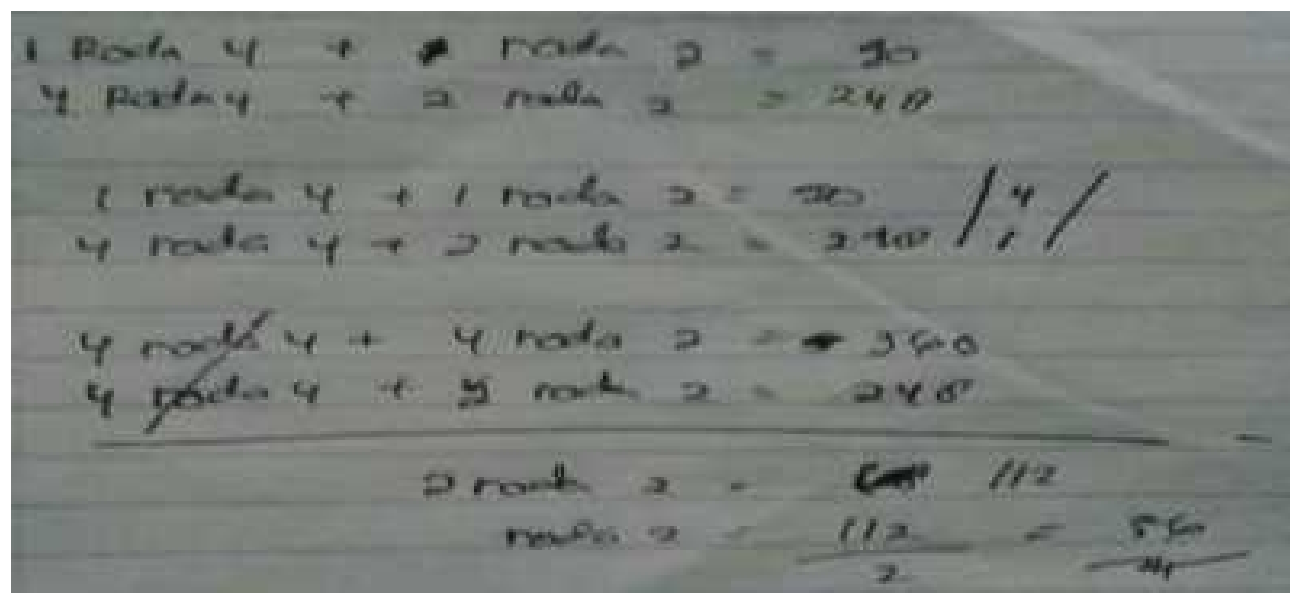

Gambar 1. Hasil Jawaban Subjek A 
Dari Gambar di atas terlihat bahwa subjek A tidak menuliskan kalimat matematika dari soal yang diberikan, namun telah baik dalam merumuskan fungsinya. Selanjutnya subjek A menggunakan metode eliminasi untuk menyelesaikan kedua persamaan tersebut. Ketika melakukan operasi, subjek A kurang teliti sehingga jawaban akhir yang didapat kurang
tepat.Berdasarkan jawaban dari subjek A dapat disimpulkan bahwa, subjek A belum paham akan soal yang diberikansehingga ketika mengerjakannya belum mampu untuk memilih penyelesaian yang tepat.

Kemampuan pemahaman konsep siswa B terhadap soal materi SPLDV sangat kurang. Berikut merupakan jawaban subjek B yang mengerjakan soal secara individu.

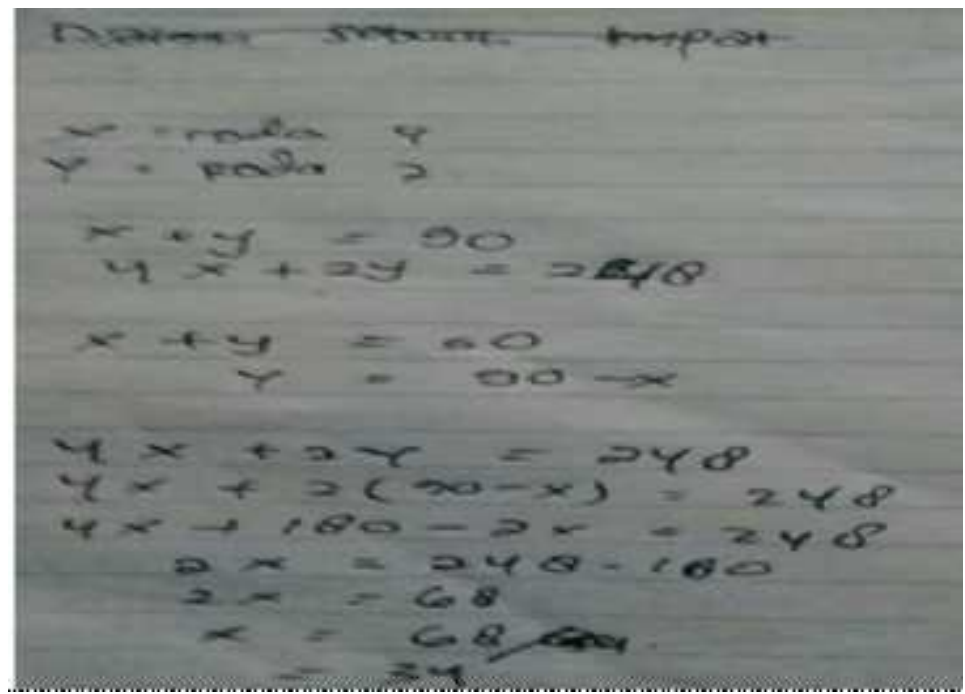

Gambar 2. Hasil Jawaban Subjek B

Pada Gambar 2 di atas dapat diketahui bahwa subjek B sudah menuliskan informasi yang ada didalam soal dalam bentuk matematika. Dengan memisalkan $\mathrm{x}$ sebagai kendaraan beroda 4 dan $y$ kendaraan beroda 2. Selanjutnya subjek B membuat kalimat matematika tersebut kedalam bentuk fungsi. Dimana fungsi y merupakan fungsi mengenai banyaknya kendaraan dan untuk fungsi yang kedua menyatakan fungsi jumlahroda seluruh kendaraan.

Berbeda dengan subjek A, subjek B menggunakan cara substitusi untuk menentukan nilai dari kedua variabelnya. Dari gambar dapat dilihat bahwa pekerjaan subjek $\mathrm{B}$ terhenti hanya sampai nilai $\mathrm{x}$ didapatkan. Sedangkan untuk nilai y - nya subjek b belum mendapatkan. Jika subjek B memasukkan nilai $\mathrm{x}$ yang didapat kedalam persamaan, maka tentu subjek B akan menemukan 56 untuk nilai y. Dari hasil jawaban subjek B dapat disimpulkan bahwa subjek kurang cermat mengerjakan soal.
Sehingga masih ada soal yang belum didapatkan jawabannya.

Kecermatan dan ketelitian sangat diperlukan dalam menyelesaikan masalah. Pemahaman konsep subjek B sudah cukup baik, subjek B mengerti apa maksud dan permintaan soal yang diberikan. Sehingga pada saat mengerjakan subjek B tidak merasa sulit.

Pada tahap penyelesaian soal yang diberikan secara mandiri terlihat bahwa subjek A dan subjek B hanya memahami sedikit konsep dari matematika materi Sistem Persamaan Linier Dua Variabel (SPLDV). Subjek mengemukakan bahwa mereka kurang paham akan konsep dari materi yang diberikan. Selanjutnya peneliti meminta mereka untuk bekerja secara berkelompok dalam menyelesaikan soal.

Ketika kedua subjek mengerjakan soal yang diberikan secara berkelompok terdapat perubahan yang sangat besar dalam jawabanmereka. Adapun jawaban dari kedua subjek dalam mengerjakan soal 
secara berkelompok dapat dilihat pada Gambar 3 berikut

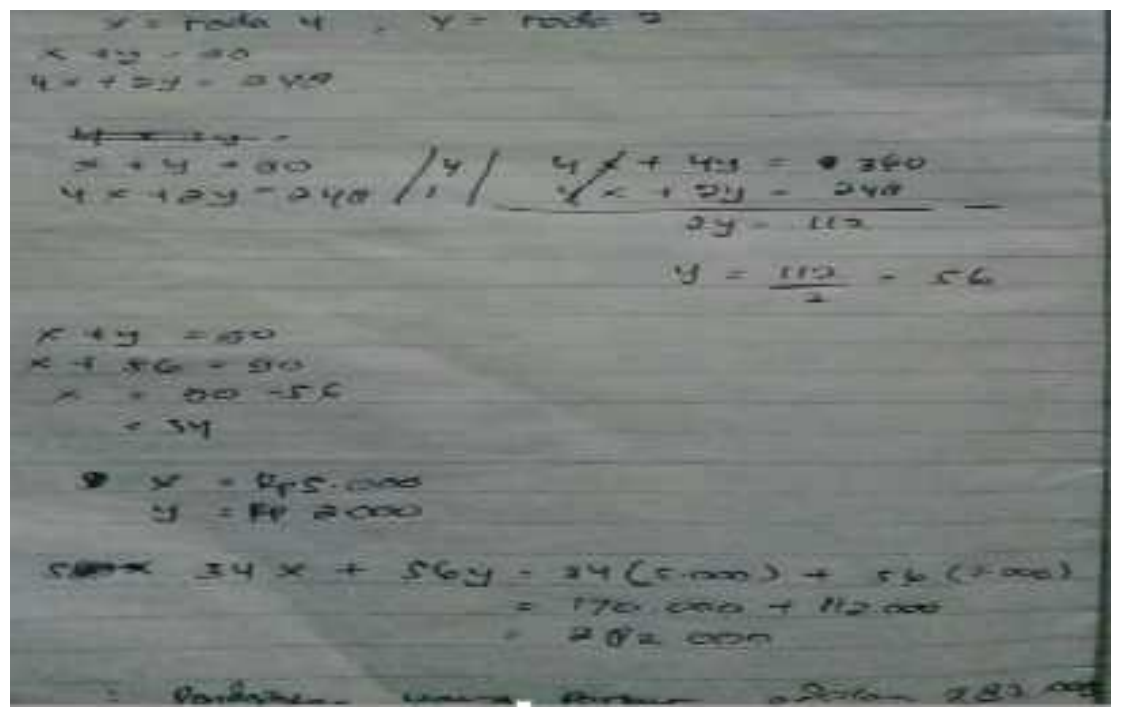

Gambar 3. Hasil Jawaban Secara Berkelompok

Pada Gambar 3 di atas terlihat bahwakedua subjek mampu mengerjakan soal yang diberikan ketika dikerjakan secara bersama-sama. Kedua subjek membuat kalimat matematika dari informasi yang diketahui dalam soal. Dengan memisalkan x sebagai kendaraan beroda 4 dan $y$ kendaraan beroda dua. Selanjutnya kedua subjek menuliskan fungsinya. Terdapat dua fungsi dari soal yang diberikan. Fungsi pertama mengenai banyaknya kendaraan dan dungsi kedua mengenai jumlah roda kendaraan.

Setelah menuliskan kedua fungsinya, subjek menyederhanakan fungsi tersebut dengan menggunakan metode eliminasi kedua fungsi. Saat nilai dari satu variabel dketahui, yaitu variabel $\mathrm{y}=56$, kedua subjek menggunakan metode substitusi untuk menentukan nilai variabel $\mathrm{x}$.

Sehingga diperoleh nilai variabel $\mathrm{x}$ adalah 34. Ketika semua nilai variabel diketahui kedua subjek melakukan operasi hitung untuk menentukan berapa pendapatan uang parkir dari kendaraan-kendaraan tersebut. Sehingga diperoleh uang pendapatan parkir dari kendaraan-kendaraan tersebut adalah Rp. 282.000,00.

Dari hasil penelitian kedua ini, menghasilkan kelompok dengan subjek yang sama diberikan soal yang sama dalam bentuk kelompok. Terjadilah pertukaran pikiran dimana siswa melakukan diskusi. Diskusi dilakukan sehingga menghasilkan informasi-informasi yang berkaitan dengan masalah yang dikemukakan. Masalah diselesaikan secara bersama-sama, sehingga menghasilkan pertukaran pikiran yang berkaitan dengan masalah. Sehingga masalah dapat diselesaikan sesuai dengan konsep matematika Sistem Persamaan Linier Dua Variabel (SPLDV).

Subjek menyatakan bahwa ketika menyelesaikan masalah secara individu, subjek mengalami kesulitan terhadap konsep-konsep matematika Sistem Persamaan Linier Dua Variabel (SPLDV). Ketika berkelompok kedua subjek dapat menyelesaikan masalah yang dikemukakan dengan saling bertukar pikiran. Pertukaran pikiran ini menghasilkan pemahamanpemahaman konsep sesuai dengan apa yang mereka ketahui yang disatukan menjadi satu kesatuan yang untuh sehingga konsep dari masalah Sistem Persamaan Linier Dua Variabel (SPLDV) dapat dipahami dengan baik.

Berdasarkan hasil wawancara yang dilakukan oleh peneliti kepada siswa pada saat selesai mengerjakan soal diketahui bahwa siswa lebih mudah mengerjakan soal 
dengan cara berkelompok. Karna dengan pembelajaran berkelompok mereka dapat mengemukakan kelemahan-kelemahannya. Dengan demikian pembelajaran yang dilakukan secara berkelompok membantu siswa untuk memahami konsep matematika dengan bantuan teman-teman sebayanya.

\section{SIMPULAN}

Kesimpulan dari penelitian ini adalah siswa kesulitan mengerjakan soal secara mandiri. Dikarekankan kurangnya pemahan siswa dan tidak adanya tempat untuk saling bertukar pikiran. Dalam rangka mempermudah pemahaman konsep berbasis masalah, lakukan diskusi kelompok agar siswa saling bertukar pikiran untuk menyelesaikannya. Materi Sistem Persamaan Linier Dua Variabel (SPLDV) adalah salah satu materi yang sesuai diterapkan secara berkelompok agar konsepnya dapat dimengerti oleh siswa.

\section{REFERENSI}

Arikunto, S. (2008). Prosedur Penelitian Suatu Pendekatan Praktek. Jakarta : Rineka

Bruno, F, J. (2010). IstilahKuncipsikologi. Yogyakarta: Kanisius.

Devis, Keith and Newstrom. (2001). Perilaku Dalam Organisasi, Edisi ketujuh. Jakarta: Penerbit Erlangga

Depdiknas. (2006). Kurikulum Tingkat Satuan Pendidikan (KTSP). Jakarta:Departemen Pendidikan Nasional.

Dimyati. (2002). Belajar Pembelajaran. Jakarta : Rineka Cipta.

Djamarah, S.,B. (2005). Guru dan Anak Didik Dalam Interaksi Edukatif. Jakarta: Rineka.

Gusniwati, M. (2015). Pengaruh Kecerdasan Emosional dan Minat Belajar Terhadap Penguasaan Konsep Matematika Siswa SMAN di Kecamatan Kebon Jeruk. Jurnal Formatif5(1): 39.

Liker, Jeffrey K, dan David Meier. (2006). Metode Penelitian. Bogor: Ghalia Indonesia.

Jennifer, M.George., and Jones. Gareth. R. (2012). Understanding and Managing
Organizational Behaviour. Sixth Edition. Pearton Education, Inc, New Jersey.

Jhonson dan Rising. (2006). Guidelines For Teaching Mathematics. Belomnt: Wodsworth Publlishing Company.

Johan, B., N. (2008). Metode Penelitian Ilmu Hukum.Bandung :Mandar Maju.

Mc Shere, S, L. and Glinow, M, A. (2007). Organizational behavior Fourth Edition. McGRAW-Hill International, United States of America.

Mukminan, dkk. (2013). Modul Pelatihan Pengembangan Keterampilan Dasar Teknik Instruksional (Pekerti): Keterampilan Dasar Mengajar. Yogyakarta: Pusat Pengembangan Kurikulum Instruksional dan Sumber Belajar Lembaga Pengembangan dan Penjaminan Mutu Pendidikan Universitas Negeri Yogyakarta.

Murizal. (2002). Pemahaman Konsep Matematika. Jakarta: PT Asli Mahasatya.

Nawawi, H \& Hadari, M.M, (1992). Instrumen Penelitian Bidang Sosial. Yogyakarta: Gajah Mada University Press.

Rahmawati, A.D. (2015). Kepetahuan Santri Terhadap Aturan di Pondok Pesantren Modern.Skripsi. Surakarta: UMS.

Robert, K. (2005). Kemampuan menurut para

ahli.http://triakurniaa.blogspot.com/201 6/12/pengertian-kemampuan-menurutpara-ahli.html $? m=1$. Diakses 25 juli 2020.

Salamun. (2009). Metode Pembelajaran. Bandung: Refika Aditama.

Setiani, A dan Donni, J, P. (2015). Manajemen Peserta Didik dan Model. Pembelajaran: Cerdas, Kreatif dan Inovatif. Bandung: CV. Alfabeta.

Sudjana. (2005). Metode Statistika. Bandung: Tarsito.

Sugiyono. (2005). Prosedur Penelitian suatu Pendekatan Praktik. Jakarta: Aneka Karya.

Sutikno, S. (2009). Belajar dan Pembelajaran. Bandung: Prospect 
Jurnal MATH-UMB.EDU

Vol 8 (1), Tahun 2020

Suryono dan Hariyanto. (2011). Belajar dan Pembelajaran. Bandung: PT Remaja. Rosdakarya.

Wardhani. (2008). Penelitian Tindakan Kelas. Jakarta: Universitas Terbuka

Yunuka, L. (2016). Kemampuan Pemahaman Konsep Matematika MahasiswaMelalui Penerapan Lembar Aktivitas Mahasiswa(LAM) Berbasis TeoriApospadaMateri Turunan. Universitas PGRI Palembang. Edumatica Volume 06 Nomor 01 April ISSN 2088-2157. 